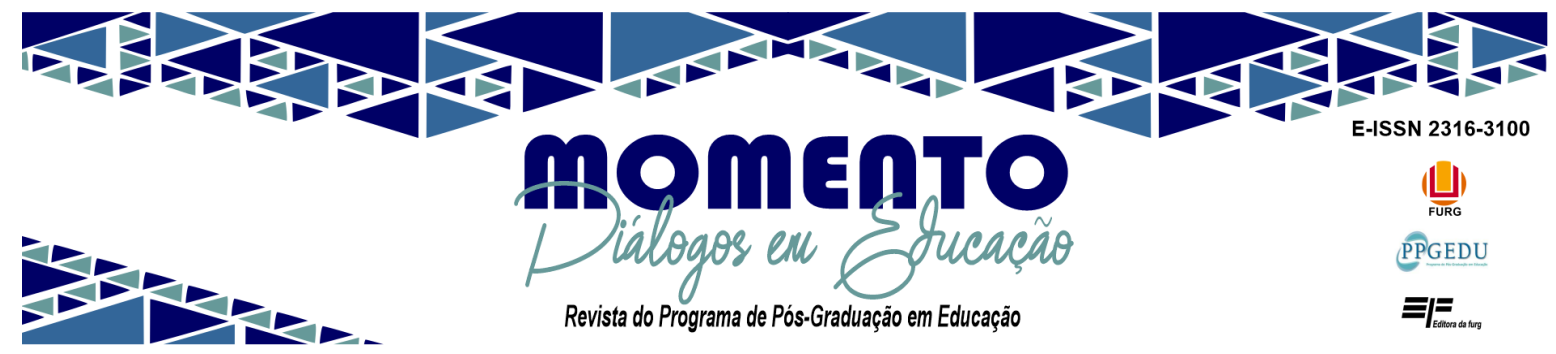

\title{
CONCEPÇÕES INFANTIS SOBRE A PALAVRA DURANTE O PROCESSO DE ALFABETIZAÇÃO
}

\author{
Carmen Regina Gonçalves Ferreira ${ }^{1}$
}

\begin{abstract}
Resumo: No presente artigo, dados de segmentação vocabular, produzidos durante a alfabetização, foram descritos e analisados com vistas à discussão concernente a aspectos relevantes para a constituição da noção de palavra durante o período inicial de desenvolvimento da escrita. Objetivase verificar quais são as hipóteses de escrita infantil no que diz respeito aos limites gráficos entre as palavras para analisar como a criança em fase de alfabetização evolui até chegar à demarcação de fronteiras vocabulares conforme a norma, bem como ao entendimento do que constitui uma palavra. Os dados apresentados são referentes a duas crianças pertencentes ao $3^{\circ}$ ano de alfabetização de uma escola pública, coletados por meio de entrevistas que visaram indagar sobre o que a criança entendia ser uma palavra (CARRAHER, 1989). A interpretação das respostas teve o suporte da teoria dos constituintes prosódicos (NESPOR, VOGEL, 1986). Os resultados da análise mostraram que, de modo geral, a criança pode oscilar ou manter as concepções iniciais sobre o que seja uma palavra como o entendimento que cada sílaba constitui uma palavra. No entanto, para a inteligibilidade do que está escrito, a segmentação vocabular parece assumir importância para a leitura segundo as explicações infantis. Evidenciando, assim, o quanto a trajetória da criança em direção à palavra escrita não é linear e apresenta multiplicidade de acepções.
\end{abstract}

Palavras-chave: Alfabetização. Aquisição da Escrita. Palavra.

\section{CHILDREN'S CONCEPTIONS OF THE WORD IN THE LITERACY PROCESS}

\begin{abstract}
In the present article, vocabulary segmentation data, produced during literacy, were described and analyzed with a view to discussing aspects relevant to the constitution of the notion of word during the initial period of writing development. The objective is to verify what are the hypotheses of children's writing with regard to the graphic limits between words to analyze how the child in the literacy phase evolves until reaching the demarcation of vocabulary boundaries according to the norm, as well as the understanding of what constitutes a word. The data presented refer to two children belonging to the 3rd year of literacy at a public school, collected through interviews that aimed to inquire about what the child understood to be a word (CARRAHER, 1989). The interpretation of responses was supported by the theory of prosodic constituents (NESPOR, VOGEL, 1986). The results of the analysis showed that, in general, the child can oscillate or maintain the initial conceptions about what a word is like the understanding that each syllable constitutes a word. However, for the intelligibility of what is written, the vocabulary segmentation seems to assume
\end{abstract}

\footnotetext{
${ }^{1}$ Possui licenciatura em Letras com habilitação em Língua Portuguesa e Literatura (FURG), licenciatura em Pedagogia (UNINTER), especialização em Ciências Sociais na Educação (URCAMP), mestrado em Educação (UFPel) e doutorado em Educação (UFPel). É membro do grupo de pesquisa GEALE - UFPel (Grupo de Estudos sobre a Aquisição da Linguagem Escrita); e participa ainda do Grupo de Estudo e Pesquisa em Alfabetização e Letramento (GEALI-FURG). É membro do Laboratório de Alfabetização e Práticas de Incentivo a Leitura- LAPIL-FURG. Possui experiência nas áreas da Educação, Alfabetização, Educação Infantil, Linguística, e Formação Docente. Atualmente realiza Pós-doutorado na Universidade Federal do Rio Grande - FURG, na Faculdade de Educação, na linha de pesquisa formação de professores e práticas educativas.
} 


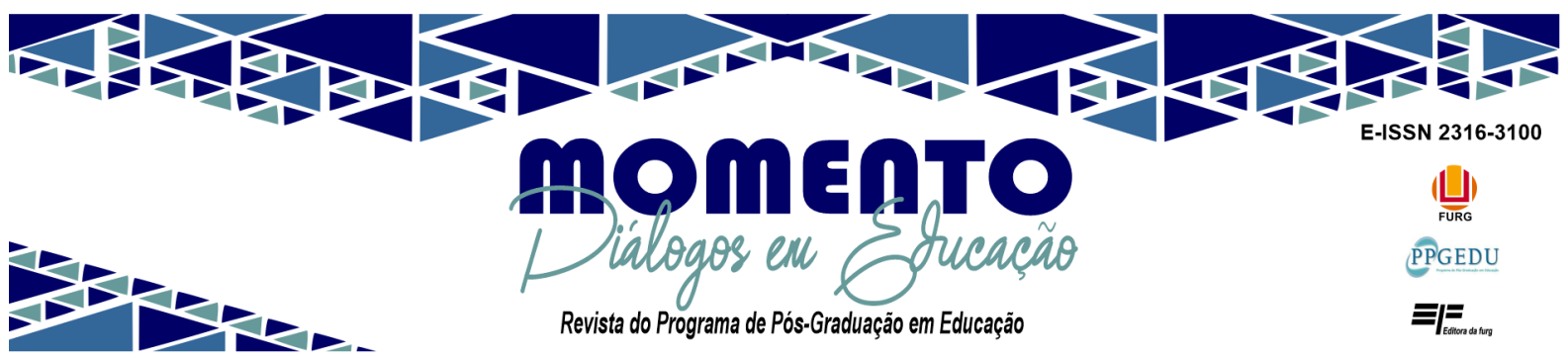

importance according to children's explanations. Thus, showing how the child's trajectory towards the written word is not linear and has a multiplicity of meanings.

Keywords: Literacy. Acquisition of Writing. Word.

\section{CONCEPCIONES INFANTILES SOBRE LA PALABRA DURANTE EL PROCESO DE ALFABETIZACIÓN}

Resumen: En el presente artículo se describieron y analizaron datos de segmentación de vocabulario, producidos durante la alfabetización, con el fin de discutir aspectos relevantes para la constitución de la noción de palabra durante el período inicial del desarrollo de la escritura. El objetivo es verificar cuáles son las hipótesis de la escritura infantil con respecto a los límites gráficos entre palabras para analizar cómo evoluciona el niño en la fase de alfabetización hasta llegar a la demarcación de los límites del vocabulario según la norma, así como la comprensión de lo que constituye. una palabra. Los datos presentados se refieren a dos niños pertenecientes al 3er año de alfabetización en una escuela pública, recolectados a través de entrevistas que tenían como objetivo indagar sobre lo que el niño entendía por palabra (CARRAHER, 1989). La interpretación de las respuestas fue apoyada por la teoría de los constituyentes prosódicos (NESPOR, VOGEL, 1986). Los resultados del análisis mostraron que, en general, el niño puede oscilar o mantener las concepciones iniciales sobre lo que es una palabra entendiendo que cada sílaba constituye una palabra. Sin embargo, para la inteligibilidad de lo escrito, la segmentación del vocabulario parece cobrar importancia según las explicaciones de los niños. Así, mostrar cómo la trayectoria del niño hacia la palabra escrita no es lineal y tiene una multiplicidad de significados.

Palabras clave: Alfabetización. Adquisición de Escritura. Palabra.

\section{Considerações iniciais}

É relativamente fácil para adultos alfabetizados o reconhecimento de uma palavra escrita que está atrelado às cadeias de letras separadas por espaços em branco. No entanto, não são apenas simples espaços. A segmentação gráfica, segundo Catach (1996), define tanto marcas de legibilidade que permitem ao leitor a identificação de grupos de letras e seus significados, como marcas gramaticais que exigem do leitor ou escrevente a reconstrução de noções morfossintáticas. Portanto, aprender a escrever é, em parte, aprender os limites que determinam onde iniciam e onde acabam as palavras, assim como o uso de outras marcas gráficas como a quebra de linhas, os sinais de pontuação e o uso de letra maiúscula (ROSA, 2006).

A noção de palavra é, portanto, antes de tudo, um desafio linguístico, já que é difícil identificar, também nos enunciados falados, as fronteiras de palavras, por serem instáveis ou 


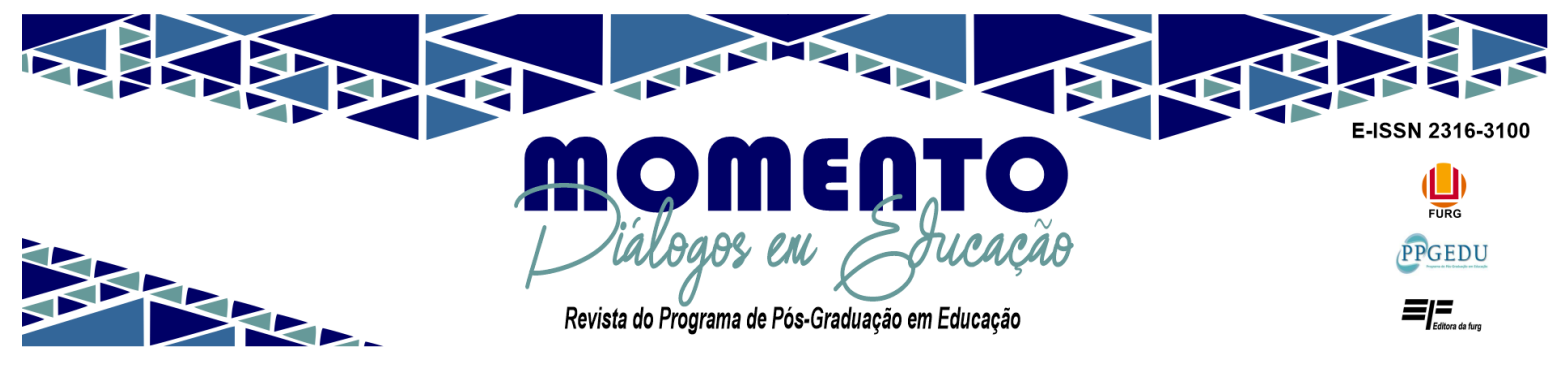

de difícil identificação. Tal instabilidade é registrada muitas vezes na escrita produzida em desacordo com as formas que, convencionalmente, são consideradas corretas no sistema de representação da escrita, resultando assim nos casos de segmentação não convencional.

Como no início da alfabetização as crianças ainda não conhecem as convenções do sistema de escrita, estão mais livres para formular hipóteses e buscar possibilidades muitas vezes nada convencionais, porém possíveis, que podem indicar regularidades e/ou singularidades relevantes à área da aquisição da escrita, como, por exemplo, a juntura de palavras que deveriam estar separadas, hipossegmentação (acasa/a casa) ou mesmo a inserção indevida de espaços no interior da palavra, hipersegmentação (a migo/amigo) (FERREIRO, PONTECORVO, 1996) ou ainda os casos de híbridos² (elaerau ma miga legal/Ela era uma amiga legal) (CUNHA, 2010).

Essas dificuldades observadas no processo de aprendizagem da escrita, no que diz respeito à noção de palavra, a partir dos processos de segmentação, têm sido o foco de atenção de muitos pesquisadores que se atêm ao estudo da escrita inicial infantil (ABAURRE 1991; BAEZ, 1999; CHACON, 2004, 2005; CAPRISTANO, 2007; CUNHA, 2004, 2010; CAPRISTANO, CHACON, 2014|). Tais estudos descreveram e analisaram a escrita inicial infantil como produto final de uma construção do escrito e colocaram a discussão sobre a noção de palavra no centro dessa problemática.

A fim de ampliar os estudos que tratam dessa instabilidade gráfica da criança, temse como objetivo analisar como a criança vai, ao longo da alfabetização, elaborando suas hipóteses de escrita no que diz respeito aos limites gráficos entre as palavras, e como evolui até chegar, não só à demarcação de fronteiras vocabulares conforme a norma, mas ao entendimento do que constitui uma palavra levando em consideração as próprias explicações infantis produzidas durante seus registros. Desta forma, o presente estudo pode subsidiar reflexões acerca de como o próprio processo de aquisição da escrita vai aos poucos se constituindo sob a ótica de quem o está adquirindo.

\footnotetext{
2 Também nomeados como mesclas (CHACON, 2005).
} 


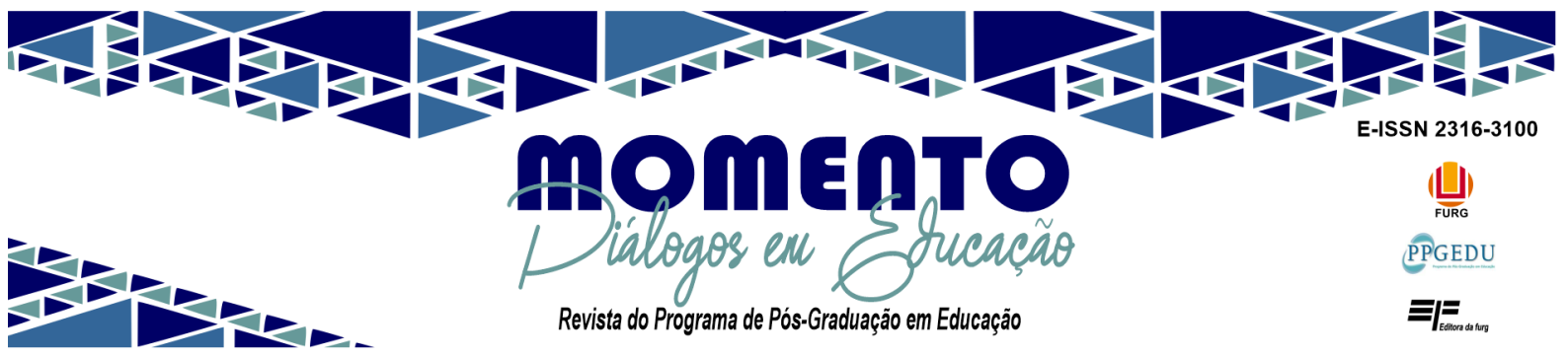

\section{Pressupostos teóricos}

As dificuldades de aprendizagem da escrita, no que diz respeito à instabilidade da noção de palavra, com base nos processos de segmentação vocabular, têm sido a temática de estudo de muitos pesquisadores ao investigar a escrita inicial infantil, como os estudos de Abaurre (1991, 1993, 1997), Abaurre e Cagliari (1985), Baez (1999), Chacon (2004, 2005, 2006, 2007), Capristano (2003, 2007, 2010) e Cunha (2004, 2010), dentre outros. Nesses estudos, o processo de aquisição da escrita de crianças ganha o estatuto de espaço de reflexão sobre os critérios linguísticos que poderiam ser motivadores das ocorrências de grafia de palavra de forma não convencional.

Os estudos de Abaurre (1991, 1993, 1997), Abaurre e Cagliari (1985), são referências para os pesquisadores que procuram interpretar as diversas questões que podem estar envolvidas nos processos de segmentação não convencional. A tarefa de descobrir o que vem a ser uma palavra é, segundo esses autores, um dos muitos problemas que o alfabetizando enfrenta ao se deparar com o sistema de escrita. Tais problemas podem ser de ordem prosódica, sintática e semântica. E os critérios utilizados pelas crianças na tentativa de representar o sistema de escrita configuram-se em indícios da forma como estão construindo um conhecimento sobre a sua língua.

Segundo Abaurre (1991), em relação aos aspectos sintáticos, salienta que os textos espontâneos permitem a observação de situações em que a criança hipossegmenta clíticos ${ }^{3}$ com palavras de conteúdo ${ }^{4}$ mesmo quando não representam um diálogo, como: 'efalou' (e falou), 'ofim' (o fim), 'naalmadilia' (na armadilha). Diversas vezes esses clíticos não são representados na escrita infantil como uma unidade linguística independente; as crianças os interpretam como se fossem parte integrante da palavra de conteúdo que os sucede. É difícil para a criança em fase de alfabetização entender que letras isoladas também constituem palavras; por isso, os clíticos são vistos pelo aprendiz como não-palavras. Para Ferreiro e

\footnotetext{
${ }^{3}$ Os clíticos abordados nesse estudo dizem respeito aos monossílabos átonos, como artigos: a(s), o(s); determinadas preposições: com, de, em, por e as contrações com artigos: $d e+o(s)=d o(s)$, de $+a(s)=d a(s)$; pronomes pessoais do caso oblíquo: me, te, se, lhe(s), nos, vos, o(s) e a(s) e algumas conjunções: e, ou, mas.

4 São geralmente substantivos, verbos, adjetivos e advérbios.
} 


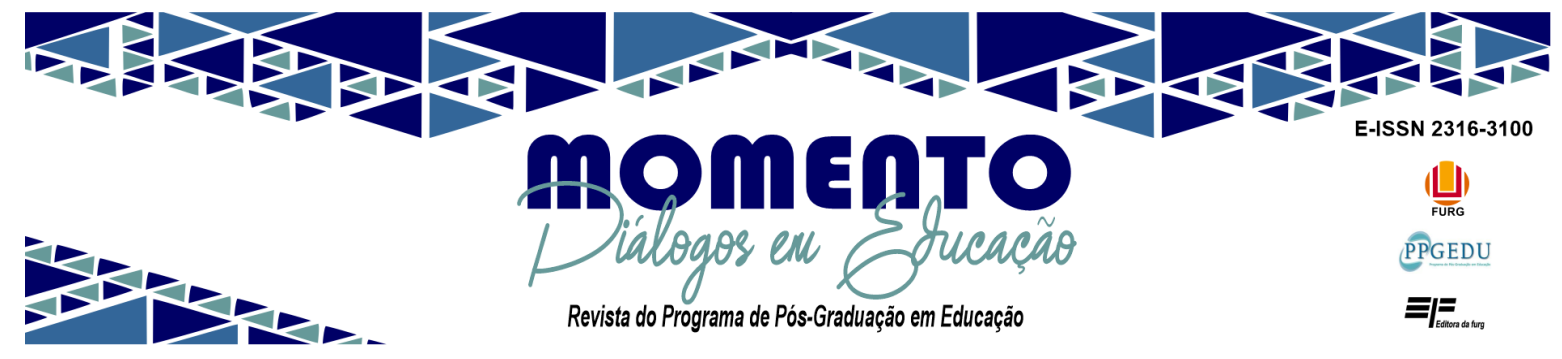

Pontecorvo (1996), a criança provavelmente perceberá que palavras são mais do que substantivos, adjetivos ou verbos quando estiver em contato com a língua de forma sistematizada na escola.

De acordo com Abaurre (1991), as crianças parecem, em alguns momentos, quando segmentam seus textos, basearem-se também no que estão momentaneamente adotando como forma "canônica" de palavra. No português do Brasil, o acento mais frequente é o das paroxítonas e, interessantemente, as escolhas de onde segmentar as palavras na escrita das crianças coincidem com esse padrão paroxítono. Cagliari (2002) também sugere que boa parte das motivações que resultam em processos de hipersegmentação possa estar sendo influenciada pela acentuação tônica da palavra.

Além de critérios prosódicos, de acordo com Abaurre (1991), critérios semânticos também podem interferir no momento da segmentação de uma palavra, como no exemplo de 'catapulta', grafada como 'cata puta', dois vocábulos existentes na língua de forma independente. Ao analisar esse exemplo, a autora acredita que a criança tenha sido motivada por dois fatores simultaneamente: o reconhecimento de duas palavras do léxico e a preferência natural por paroxítonas dissílabas. Não há como determinar com certeza quais critérios estariam por trás das escolhas de segmentação de cada criança. É possível, porém, de acordo com os estudos de Abaurre (1991), verificar que, frequentemente, os aprendizes propõem soluções que parecem estar baseadas em algum tipo de informação relativa às formas canônicas de palavras da língua, percepção que eles já possuem a respeito da organização rítmica e prosódica dos enunciados.

Baez (1999), no seu estudo referente à segmentação não convencional com crianças argentinas, verificou que as justificativas utilizadas pelas crianças a respeito de suas escolhas de onde segmentar partem de critérios de ordem formal, gráfica e quantitativa, concentrandose mais nos aspectos sintáticos e semânticos. O critério que parece ter maior consenso é o da legibilidade, pois as crianças desde muito cedo percebem a segmentação como algo necessário para garantir o ordenamento e a significação do texto.

A vinculação que as crianças fazem das segmentações com a atividade de leitura confere um sentido mais ligado à necessidade que à simples convenção, o que parece assinalar que as segmentações não constituem em si função linguística, mas são 


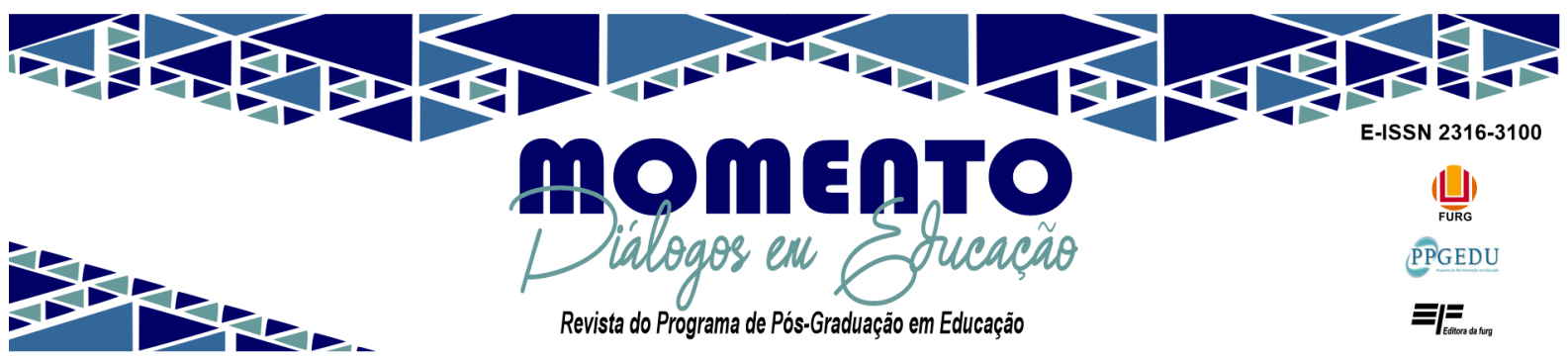

indispensáveis nos momentos de leitura e escrita. No entanto, no caso, a legibilidade remete a uma representação mental de caráter lexical e morfossintático, dada a experiência mais prolongada de interação com os textos (BAEZ, 1999).

Ainda, no que se refere aos estudos sobre segmentação, temos a pesquisa de Cunha (2004), que apresenta importantes contribuições por oferecer uma descrição minuciosa dos processos de segmentação não convencional na escrita inicial infantil, estabelecendo estreita relação entre os dados obtidos e os constituintes prosódicos ${ }^{5}$. Segundo a autora, os dados de hipossegmentação parecem ser influenciados pelos constituintes mais altos da hierarquia prosódica, da palavra fonológica ao enunciado, enquanto os dados de hipersegmentação parecem ser motivados pelos constituintes mais baixos, a sílaba e o pé. A relação estabelecida por Cunha (2004), entre as segmentações não convencionais e a prosódia, aponta para evidências, na escrita, do conhecimento fonológico que a criança possui sobre sua língua.

Há trabalhos que diferem um pouco quanto à abordagem do fenômeno das segmentações não convencionais, como é o caso dos trabalhos de Chacon (2004, 2006, 2007), Capristano (2003, 2007), Paula (2007) e Tenani (2004) que, além dos aspectos linguísticos, enfatizam os discursivos. A hipótese central que norteia esses estudos é demonstrar que as segmentações não convencionais no processo inicial da escrita infantil resultam, simultaneamente, do trânsito do sujeito escrevente por práticas orais e letradas, fato que aponta para um modo heterogêneo de constituição da escrita, conforme proposto por Corrêa (2004).

Chacon (2007), ancorado nos pressupostos das relações estabelecidas entre os constituintes prosódicos e as convenções ortográficas, analisou os aparentes conflitos que a criança enfrenta nos diversos momentos em que precisa grafar determinadas palavras e

\footnotetext{
${ }^{5}$ Segundo Nespor e Vogel (1986), os constituintes prosódicos são unidades resultantes de uma teoria de organização do enunciado em unidades fonológicas organizadas hierarquicamente, na qual a fala é representada por um sistema em que cada constituinte da hierarquia atua como contexto de aplicação de regras e de processos fonológicos específicos. Estes constituintes não possuem uma relação de equivalência com constituintes sintáticos e morfológicos, apesar de serem formulados a partir de informações obtidas a partir destes. São, portanto, sistemas que atuam de maneira própria, mas que mantém uma relação entre si.
} 


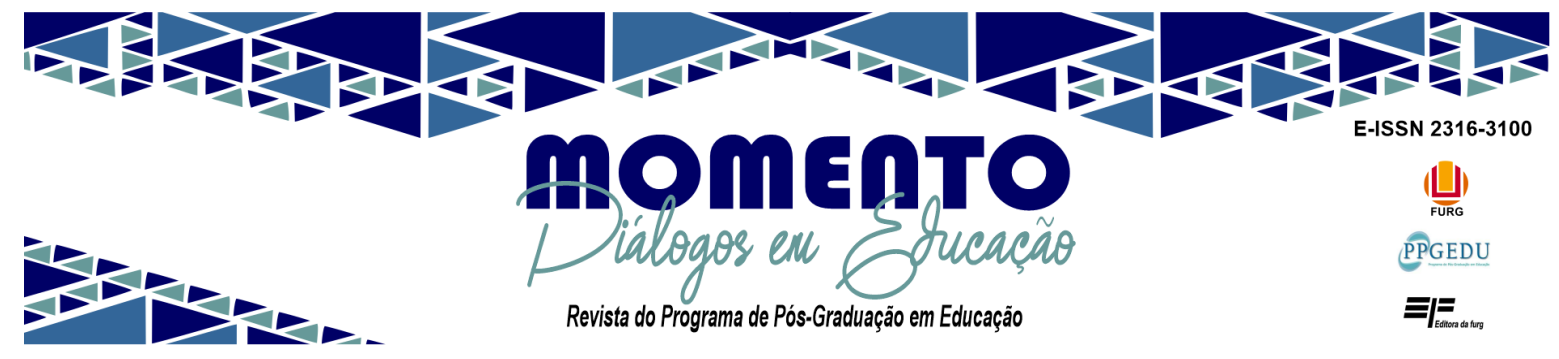

verificou que esses episódios de indecisão são verificáveis através de marcas de flutuação ${ }^{6}$ na escrita infantil. As flutuações correspondem não só às formas distintas de grafar a mesma palavra, mas também às que são fruto de um processo de apagamento verificável nas marcas da estrutura escrita. E tais movimentos são marcados diversas vezes tanto por aspectos prosódicos da língua quanto por práticas de oralidade, ambos característicos da constituição do sujeito como falante.

Seguindo a mesma perspectiva teórica, Capristano (2003) reafirma o pressuposto da heterogeneidade da escrita ao analisar a segmentação não convencional infantil e verifica que os dados resultantes dessa escrita segmentada apontariam para dois fatores relevantes: o funcionamento linguístico da escrita infantil e os processos de subjetivação do alfabetizando.

Com base no pressuposto de que o processo constitutivo do sujeito escrevente é uma ação ininterrupta, por estar sempre se envolvendo em novas práticas orais e letradas, Capristano (2007) constata que o processo de aquisição da escrita não segue uma linha direta, com acúmulos graduais, como se cada sujeito tivesse um estado zero e um estado final; não há começo nem fim. A aquisição da escrita constitui-se no que a autora nomeia como 'as metamorfoses mais inesperadas', pois os episódios de idas e vindas, reduções, desaparecimentos, etc., fazem parte desse processo marcado por flutuações e movimentos não lineares.

Todas as pesquisas sobre segmentações não convencionais referidas nesta seção reafirmam o quanto esses processos de segmentação são reveladores de um modo de pensar e refletir sobre a língua sob a ótica de quem está apreendendo esse sistema e muito podem contribuir na interpretação dos dados que objetivam investigar como a criança constitui a noção de palavra durante o processo de alfabetização.

\section{Metodologia}

A metodologia do presente estudo caracteriza-se como qualitativa (BOGDAN, BIKLEN, 1994), na medida em que procurou descrever e analisar dados de segmentação

\footnotetext{
${ }^{6}$ Flutuação é um termo que designa as diferentes formas de grafar a mesma palavra presentes no mesmo contexto de escrita. Ex.: em pé < inpe < en pé (CHACON, 2007).
} 


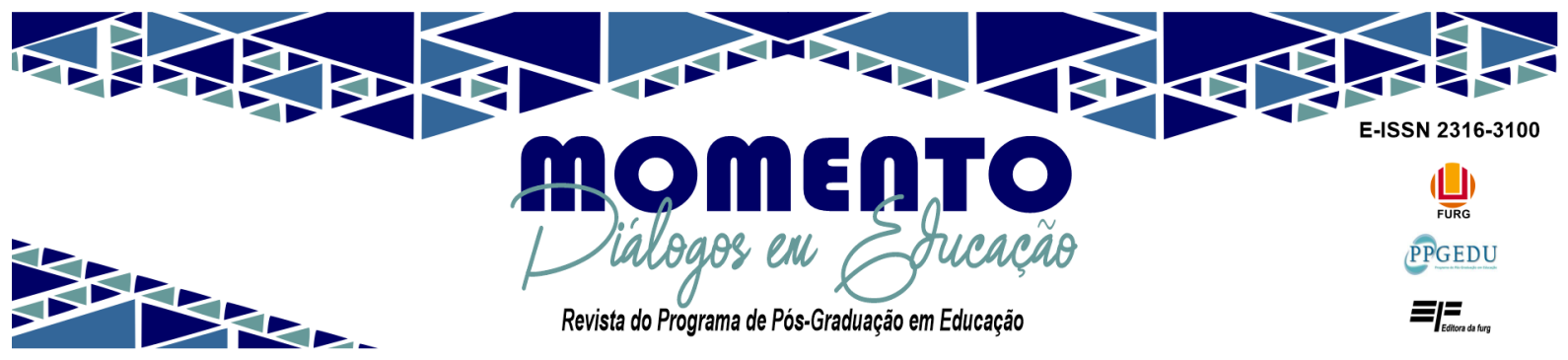

presentes na escrita inicial infantil, a fim de discutir aspectos relevantes à constituição da noção de palavra. Pode-se dizer que esse tipo de abordagem, amplamente usado na área educacional, favorece o conhecimento aprofundado sobre uma temática para verificar o que estaria interferindo ou influenciando na ocorrência de determinado fenômeno.

Para o presente estudo fez-se um recorte dos dados que pertencem a uma pesquisa mais ampla e a partir de um estudo de caso (GIL, 2007) serão apresentados os dados de duas crianças, Kauan e Eduarda ${ }^{7}$, que na ocasião das coletas frequentavam o $3^{\circ}$ ano do ciclo de alfabetização de uma escola municipal.

Como forma de se construir relações de pesquisa com as crianças, que sejam mais horizontais e respeitadoras a elas enquanto atores sociais (FERNANDES, 2009), o assentimento para participar da pesquisa foi registrado por meio de gravação (vídeo), no qual esclareceu-se às crianças os interesses e objetivos da pesquisa. Salientou-se para cada uma delas, que a participação seria encerrada mediante o desinteresse das mesmas em qualquer estágio do desenvolvimento da pesquisa. Além disso, foi enviado para os pais um termo de consentimento, por escrito, que deveria ser entregue assinado.

As coletas foram organizadas de forma que pudessem captar o que 'provisoriamente' as crianças estavam concebendo como palavra, tendo em vista os possíveis obstáculos de ordem linguística fonológica, morfológica, semântica bem como lexical. E foram coletadas no início, meio e final do ano letivo, por meio de entrevistas individuais, realizadas numa sala reservada na escola, onde foram filmadas e conduzidas com o método clínico piagetiano, conforme proposto por Carraher (1989), com o propósito de compreender as razões das escolhas gráficas infantis. Além das filmagens foram utilizados para análise, registros escritos das crianças para que se pudesse confrontar as respostas oriundas das entrevistas, com as escolhas gráficas utilizadas nas demarcações dos espaços em branco entre as palavras. Para tal, criou-se um conjunto de tarefas para verificar quais os critérios utilizados pela criança para identificar uma palavra num fluxo contínuo, como podem ser observadas no quadro a seguir:

\footnotetext{
${ }^{7}$ Os nomes serão fictícios para preservar a identidade dos sujeitos.
} 


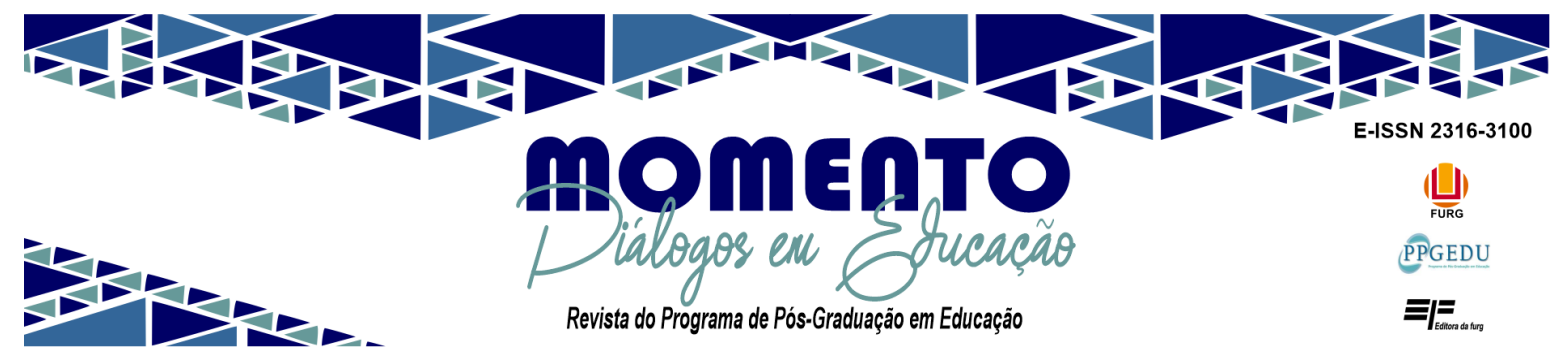

Quadro 1 - Conjunto de tarefas de segmentação em escrita contínua ${ }^{8}$

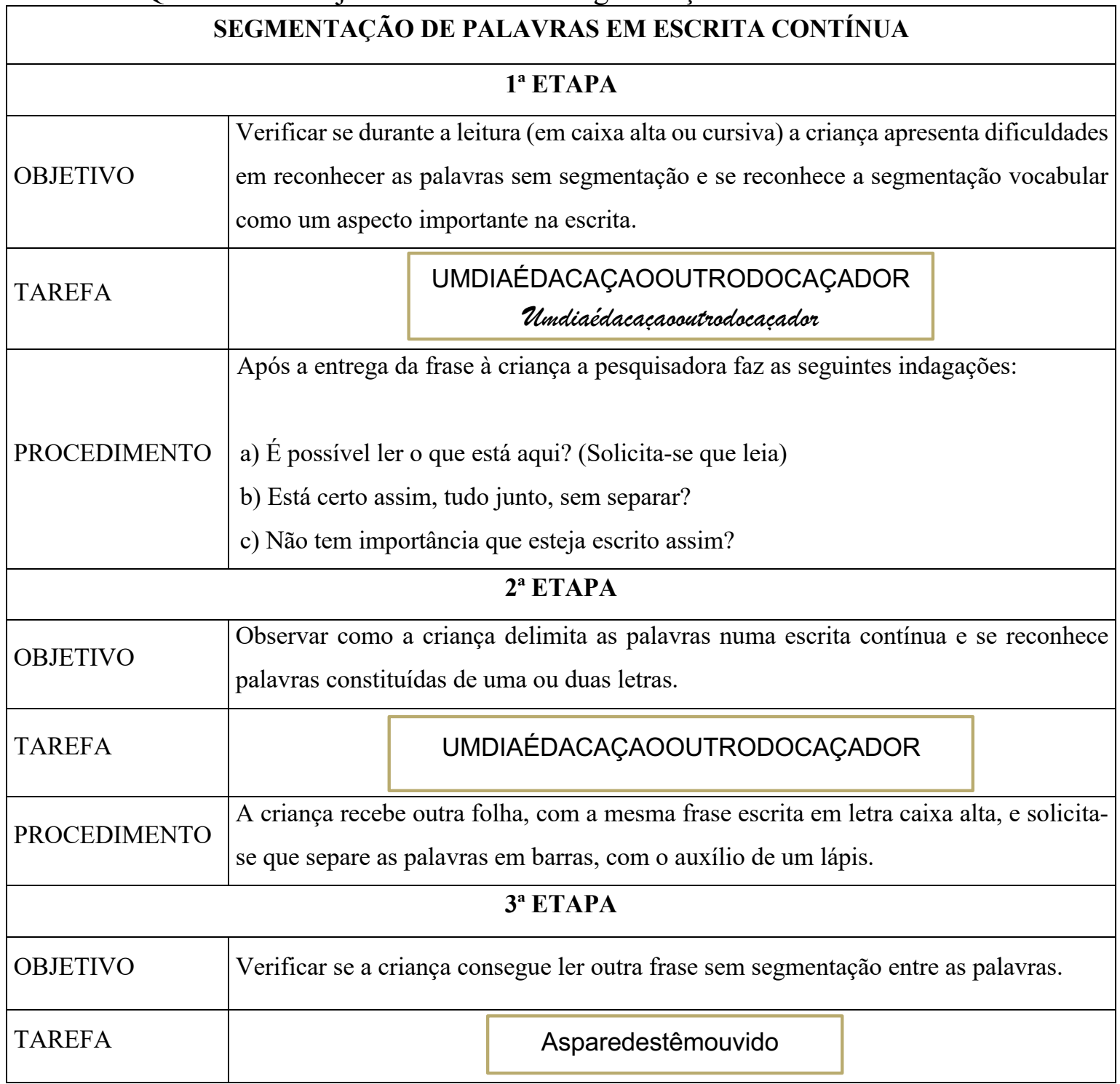

\footnotetext{
${ }^{8} \mathrm{O}$ conjunto destas tarefas juntamente com seus objetivos e procedimentos foram criados exclusivamente para a coleta de dados do presente estudo acerca de leitura e escrita controlada sobre segmentação de palavras em escrita contínua. Apenas a segunda etapa que consiste em separar em barras uma frase contínua que é uma adaptação de uma situação experimental utilizada no estudo de Ferreiro (2000): Entre a sílaba oral e a palavra escrita in: Emília Ferreiro O ingresso na escrita e nas culturas do escrito (2003).
} 


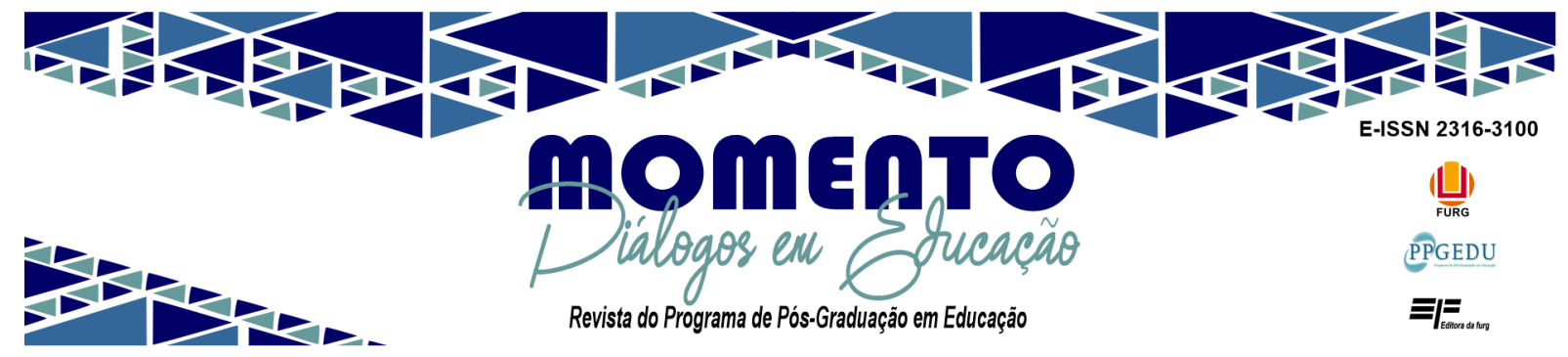

\begin{tabular}{|l|l|}
\hline PROCEDIMENTO & $\begin{array}{l}\text { Solicita-se à criança que leia uma frase sem segmentação entre as palavras escrita em } \\
\text { letra Arial, tamanho 12, com apenas a primeira letra em maiúscula e as demais } \\
\text { minúsculas. }\end{array}$ \\
\hline OBJETIVO & $\begin{array}{l}\text { Observar que estruturas a criança considera como palavra ao ter que decidir que } \\
\text { palavras ocuparão os quadradinhos. }\end{array}$ \\
\hline TAREFA & \multicolumn{2}{|c|}{ Asparedestêmouvido } \\
\hline PROCEDIMENTO & $\begin{array}{l}\text { Solicitar que a criança escreva dentro dos quadradinhos as palavras da frase acima e } \\
\text { após leia. }\end{array}$ \\
\hline OBJETIVO & $\begin{array}{l}\text { Verificar quais as hipóteses que a criança apresenta frente duas diferentes formas de } \\
\text { segmentação, visto que o escrito convencional está presente. }\end{array}$ \\
\hline TAREFA & \begin{tabular}{|c|c|} 
Asparedestêmouvido \\
As paredes têm ouvido
\end{tabular} \\
\hline PROCEDIMENTO & $\begin{array}{l}\text { Solicitar que a criança tente ler a frase hipossegmentada e, depois, a segunda frase, } \\
\text { segmentada de forma convencional. Após, a criança deve julgar qual delas ficaria } \\
\text { melhor para ler. }\end{array}$ \\
\hline
\end{tabular}

Fonte: Elaboração própria.

Convém ressaltar que tanto na $2^{\mathrm{a}}$ quanto na $4^{\mathrm{a}}$ etapa, a criança que desejasse refazer a separação das palavras, receberia outra folha igual para que se mantivessem todas as formas de registro elaboradas por ela. Embora o número de quadrados, na $4^{\mathrm{a}}$ etapa, correspondesse à quantidade de palavras segmentadas de forma convencional, não se desconsiderou a possibilidade desse aspecto interferir na forma como a criança segmentaria as palavras, pois, logo no início, nesta etapa, foram orientadas pela pesquisadora para acrescentar outros quadradinhos ou deixar algum em branco se julgassem necessário.

\section{Descrição e análise dos dados}

Apresenta-se a seguir os dados de Kauan e logo após os de Eduarda com o objetivo de verificar como ao longo da alfabetização vão elaborando suas hipóteses de escrita no que 


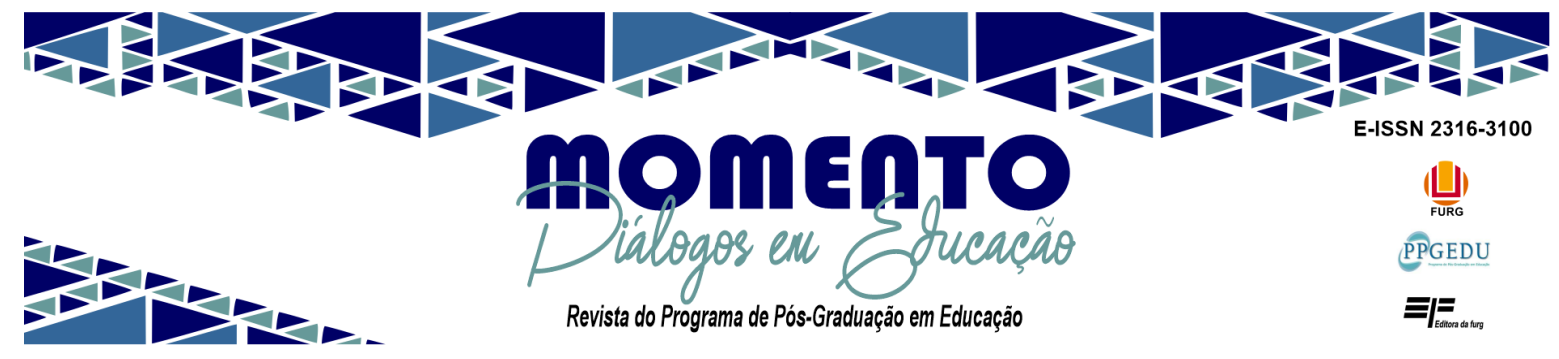

diz respeito aos limites gráficos entre as palavras, e como evolem ou não até chegar, não só à demarcação de fronteiras vocabulares conforme a norma, mas também ao entendimento do que constitui uma palavra no sistema de escrita.

\section{a) Tarefa de segmentação de palavras em escrita contínua - Kauan}

$\mathrm{Na} 1^{\mathrm{a}}$ tarefa, em que precisava julgar se uma frase toda hipossegmentada poderia ser lida, a criança apresentou dificuldades para ler. No momento em que precisou separar a frase em barras, na $2^{\text {a }}$ etapa, realizou da seguinte forma:

\section{Umdiaé dacaça o outrodo caçador.}

Após realizar esta separação entre as palavras que originou três casos de hipossegmentação: 'umdia' (um dia), 'dacaça' (da caça), 'outrodo' (outro do), originando palavras fonológicas ${ }^{9}$, constituídas pela juntura do clítico à palavra de conteúdo (ABAURRE, 1991; CUNHA, 2004) e restando apenas o artigo 'o' e o substantivo 'caçador' segmentados de forma convencional, a pesquisadora perguntou à criança se cada uma daquelas estruturas eram palavras e Kauan confirmou que todas eram com exceção do 'o' porque era apenas uma letra, mas que precisava ficar separada das demais.

Como se pode perceber o fato da criança segmentar de forma convencional na escrita o artigo 'o', segundo sua justificativa, não significa que esteja considerando-o como palavra, Kauan trabalha nesse momento com a hipótese do número mínimo de caracteres como uma regularidade possível para a formação de uma palavra (FERREIRO, 1991). Muitas vezes é complexo para a criança em fase de alfabetização entender que letras isoladas também constituem palavras; por isso, os clíticos são vistos pelo aprendiz como não-palavras (FERREIRO, PONTECORVO, 1996).

$\mathrm{Na}$ etapa seguinte, com outra frase hipossegmentada 'Asparedestemouvido', a criança não apresentou dificuldades em ler e disse que a escrita das letras todas juntas não dificultava a leitura. O que parece evidenciar que Kauan apenas oralizou o que estava escrito

\footnotetext{
${ }^{9}$ A palavra fonológica é o nível da hierarquia prosódica que representa o mapeamento entre os componentes morfológicos e fonológicos de uma gramática (NESPOR, VOGEL 1986).
} 


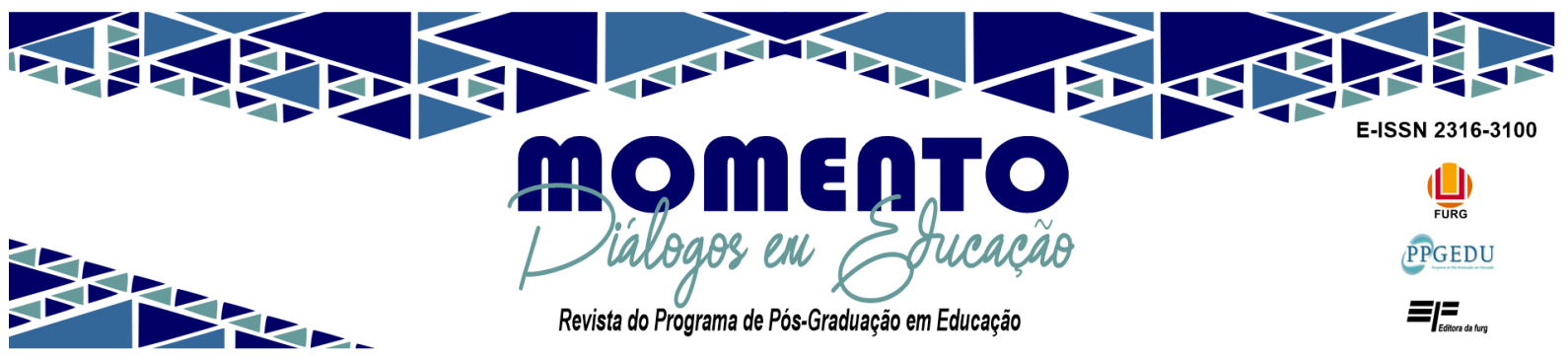

sem atribuir necessariamente sentido ao que leu. Ao ter que separar essa mesma frase em quadradinhos, na $4^{\mathrm{a}}$ etapa, realizou a seguinte segmentação:

Asparedes têm ouvido.

A criança afirmou em suas justificativas que cada uma das três estruturas separadas eram palavras, o que evidencia a oscilação entre os aspectos morfológicos e sintáticos na concepção de palavra. A estrutura 'Asparedes', embora fonologicamente possa ser interpretada como caso de hipossegmentação, do ponto de vista semântico, configura-se em uma estrutura tópico-comentário. De acordo com Pontes (1987) uma estrutura tópicocomentário constitui-se em uma construção cuja característica principal é a de colocar em evidência um elemento, chamado de tópico (As paredes), e faz-se sobre esse tópico um comentário (tem ouvidos).

Com base na análise das filmagens que capturaram o momento exato dessa escrita de Kauan, foi possível perceber que essa segmentação não convencional parece ter sido fruto de um contorno entonacional gerado pela forma como a criança murmurou as palavras enquanto escrevia. É, portanto, a forma dessa 'voz baixa' que parece orientar o contorno entonacional em determinados contextos de escrita que influencia as escolhas de onde segmentar.

Ao receber, na última etapa, essa mesma frase escrita com e sem segmentação entre as palavras, a criança leu, primeiramente, a estrutura hipossegmentada e depois a segmentada convencionalmente e julgou que a segunda estaria melhor para ler. No entanto, diante destas duas diferentes formas de segmentação vocabular a criança percebeu que a separação que havia feito anteriormente dentro dos quadradinhos estava diferente do que julgou como sendo a melhor forma de segmentar a frase. No fragmento da entrevista apresentado, a seguir, é possível conferir a sua reação:

Kauan: Essa aqui (frase segmentada convencionalmente) tá separada AS PAREDES AS PAREDES TÊM OUVIDO eu botei errado. Pesquisadora: Por que tu achas que colocou errado? 


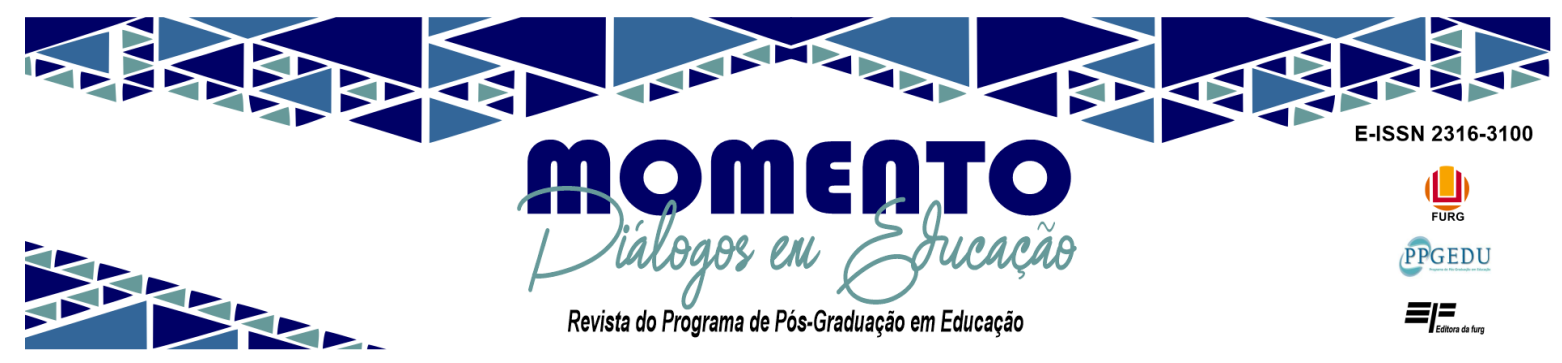

Kauan: Porque 'as' é separado e 'paredes' é separado do 'as' e 'têm' também é separado TEM OUVIDO separado do 'têm'.

A pesquisadora pegou novamente a folha dos quadradinhos, preenchida pela criança, para que ela comparasse o que tinha de diferente e confirmasse que havia hipossegmentado o artigo com o substantivo (Asparedes). Assim, diante das duas formas apresentadas (com e sem segmentação da frase) e a que Kauan tinha segmentado nos quadradinhos, a criança pode refletir sobre a forma como segmentou e comparar refazendo a sua escolha mesmo que apenas oralmente.

Na segunda coleta, realizada no meio do ano letivo, as cinco tarefas foram novamente aplicadas, mas com outras frases. $\mathrm{Na} 1^{\mathrm{a}}$ etapa, Kauan, apresentou dificuldade para ler a frase hipossegmentada 'Osolnasceparatodos' e na etapa seguinte realizou a seguinte separação em barras:

\section{Osol nasce para todos.}

Como se pode observar, ocorreu apenas um caso de juntura no início da frase, originando uma palavra fonológica constituída por um clítico com uma palavra de conteúdo 'osol' (o sol) (NESPOR, VOGEL, 1986). Na tarefa seguinte, na separação em quadradinhos, a frase 'Obaratosaicaro', a criança optou por realizar a seguinte segmentação:

\section{Obarato sai caro.}

Novamente se observa a ocorrência de um caso de juntura de um clítico com uma palavra de conteúdo: 'obarato' (o barato) em início de frase (CÂMARA JR., 1969). Assim como na hipossegmentação da frase anterior, observa-se que a criança, não admitindo uma palavra com apenas uma letra, acaba considerando o clítico como uma sílaba da palavra adjacente (FERREIRO, 1991). No entanto, sob o aspecto semântico, essa estrutura, assim como a analisada anteriormente (Asparedes), também pode ser interpretada como um tópicocomentário (PONTES, 1987).

Ao receber a mesma frase com e sem segmentação vocabular, na $5^{\mathrm{a}}$ tarefa, a criança, diferentemente da coleta anterior, julgou que ambas as formas eram possíveis de serem lidas 


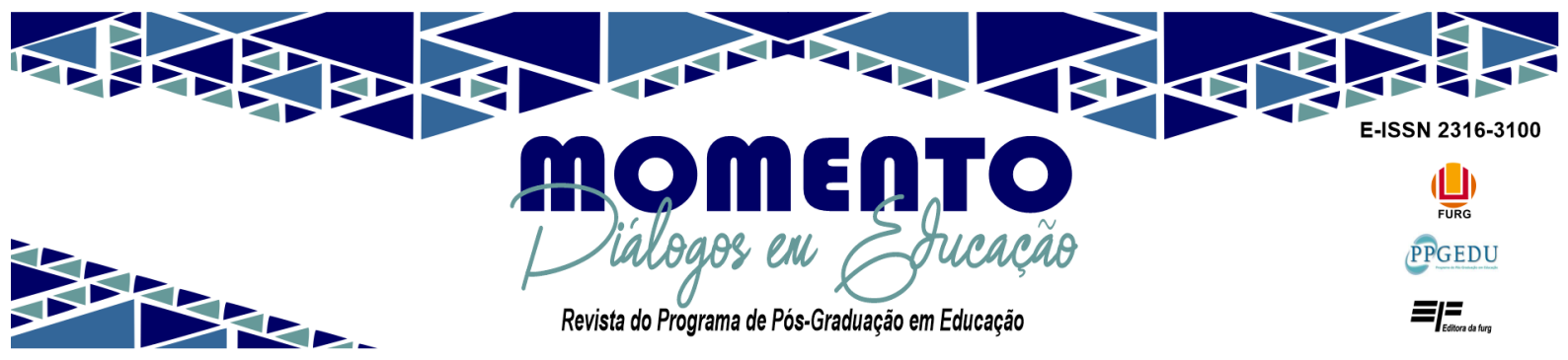

e não comparou nem analisou com a forma como teria segmentado nos quadradinhos quando gerou o caso de hipossegmentação 'Obarato' (o barato).

$\mathrm{Na}$ terceira coleta, realizada no final do ano letivo, Kauan, na $1^{\mathrm{a}}$ etapa não apresentou dificuldades em ler a frase hipossegmentada e na $2^{\mathrm{a}}$ etapa realizou a seguinte segmentação entre as palavras usando barras:

Umamão lavaa outra.

Observou-se a formação de dois dados de hipossegmentação, 'umamão' (uma mão) e 'lavaa' (lava a outra). Primeiramente uniu-se um clítico a uma palavra de conteúdo e na segunda ocorrência o inverso (CUNHA, 2010).

$\mathrm{Na}$ frase seguinte, que precisava ser colocada dentro dos quadradinhos, a criança apresentou apenas uma ocorrência de hipossegmentação 'vêcara' a primeira forma verbal 'vê' com o substantivo 'cara'. No entanto, na segunda forma verbal 'vê' presente na frase não houve junturas em desacordo com a norma, muito provavelmente porque a criança tende a evitar estruturas polissílabas 'vêcoração' (vê coração) bem como o choque de acentos que promoveria a juntura envolvendo o advérbio de negação 'nãovê' (não vê) (BISOL, 1996):

Quem vêcara não vê coração.

E na última tarefa, frente às duas formas escritas da mesma frase, segmentada convencionalmente e hipossegmentada, Kauan não só afirmou que as duas formas poderiam ser lidas sem apresentar dificuldades, como leu ambas sem problemas. E, desta vez, também não houve a percepção de que a forma como teria segmentado nos quadradinhos pudesse ser diferente das que foram apresentadas nesta última tarefa.

Observou-se, assim, que Kauan até a última coleta ainda apresentava dificuldades em delimitar as palavras na escrita. Apresentou predominância de dados de hipossegmentação sobre dados de hipersegmentação e híbridos, tendência já atestada em estudos sobre a escrita infantil, segundo a qual os dados de hipossegmentação são mais 


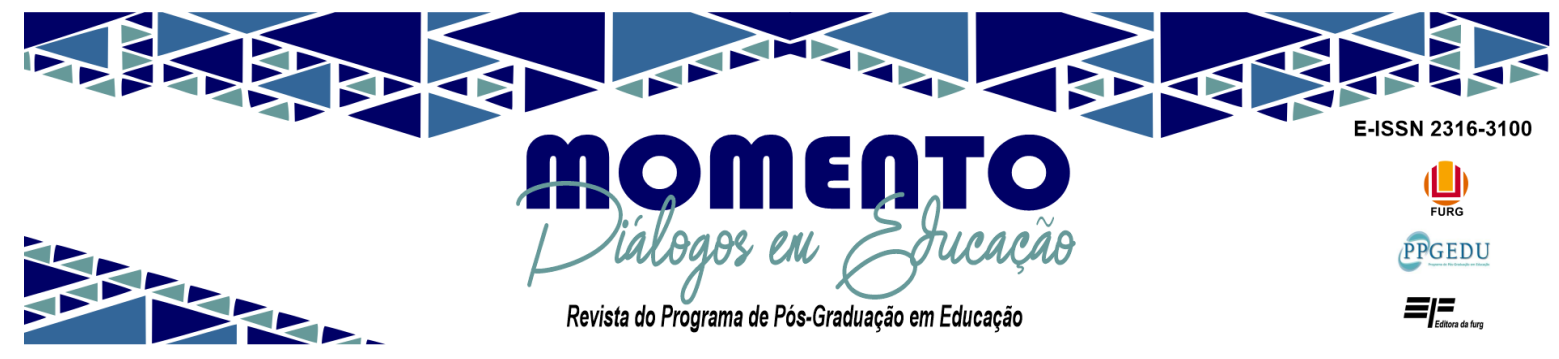

frequentes no início da alfabetização e tendem a diminuir com o avanço da escolarização (FERREIRO; TEBEROSKY, 1999; CAGLIARI, 1999).

Segundo suas justificativas, Kauan não encontrou problemas nas frases apresentadas sem segmentação entre as palavras, o que pode indiciar que o foco nas atividades em que deveria ler pareceu estar muito mais focado na oralização das estruturas hipossegmentadas do que no sentido das palavras nas frases. Segundo Baez (1999), o fato de os alfabetizandos grafarem ou tentarem ler palavras aparentemente sem sentido parece não causar estranhamento a eles, pois, quando precisam escrever pseudopalavras, o fazem sem qualquer tipo de questionamento semântico.

\section{b) Tarefa de segmentação de palavras em escrita contínua - Eduarda}

$\mathrm{Na} 1^{\mathrm{a}}$ etapa, em que precisava julgar se uma frase toda hipossegmentada poderia ser lida a criança respondeu que daria para ler e realmente a leu, sem maiores dificuldades. $\mathrm{Na}$ etapa seguinte ao ser solicitado que separasse a frase em barras, a criança realizou a seguinte separação:

\section{Um dia é da caça o outro do caça dor}

Verificou-se que, a Eduarda segmentou quase todas as palavras de forma convencional. Apenas a palavra 'caçador' foi hipersegmentada em 'caça dor'. Para se certificar de que a criança não teria se distraído no momento da segmentação, a pesquisadora perguntou-lhe se eram mesmo duas palavras que estaria separando, e Eduarda confirmou. Isso parece sinalizar que a criança não entendeu o sentido da frase, mas apenas o reconhecimento de palavras isoladas, por isso a interpretação da palavra 'caçador' como sendo duas palavras do léxico: 'caça' e 'dor'.

A criança possivelmente tenha sido motivada por dois fatores concomitantes como assinala Abaurre (1991), que seria o reconhecimento de duas palavras do léxico e a preferência natural por paroxítonas dissílabas. Segundo a autora, embora não seja possível 


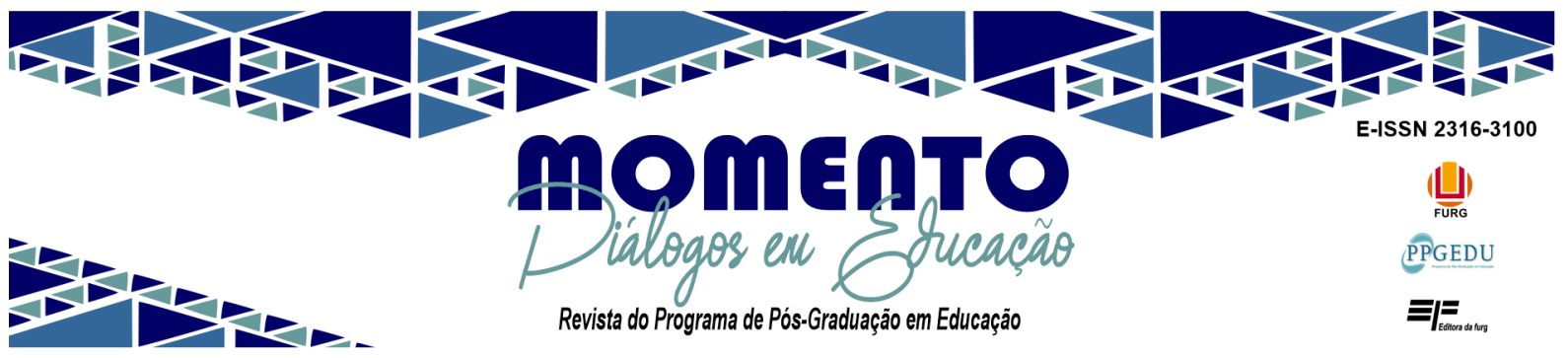

em alguns casos ter certeza de quais critérios estariam por trás das escolhas de segmentação de cada criança, é possível, no entanto, verificar que, frequentemente, os aprendizes propõem soluções que parecem estar baseadas em algum tipo de informação relativa às formas canônicas de palavras da língua, percepção que as crianças já possuem a respeito da organização rítmica e prosódica dos enunciados.

Na segunda frase hipossegmentada da $3^{\mathrm{a}}$ tarefa, a criança confirmou que poderia ser lida, e após, na tarefa seguinte, realizou a seguinte segmentação dentro dos quadradinhos (Fig.01):

Figura 01 - Tarefa de segmentação em escrita contínua - Eduarda.

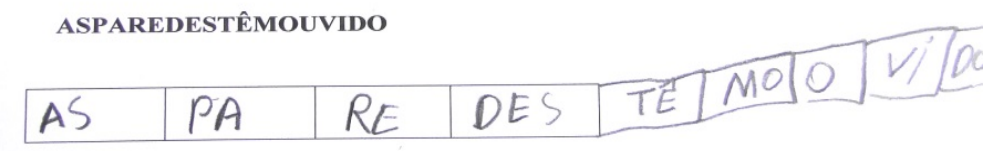

Como se pode observar a criança segmentou todas as palavras em sílabas. Como os quadradinhos não foram suficientes ela acrescentou outros para que coubessem todas as sílabas segmentadas. A pesquisadora solicitou que a criança lesse o que estava nos quadradinhos para que pudesse observar o que tinha escrito e refazer se fosse o caso. No entanto, a leitura da criança acabou confirmando que ela não estava atribuindo sentido ao que estava lendo, assim como Kauan, pois não houve estranhamento ao ler 'te mo u vido' (tem ouvido) como se pode conferir no excerto a seguir:

Eduarda: AS PA RE DES TE MO U VI DO (leitura da escrita nos quadradinhos).

Pesquisadora: Quantas palavrinhas nós temos aqui então?

Eduarda: Uma, duas, três, quatro, cinco, seis, sete, oito, nove. (contagem dos quadradinhos).

Ao receber, na etapa $5^{\mathrm{a}}$ tarefa, essa mesma frase escrita com e sem segmentação entre as palavras, a criança leu, primeiramente, a estrutura hipossegmentada da seguinte forma: 


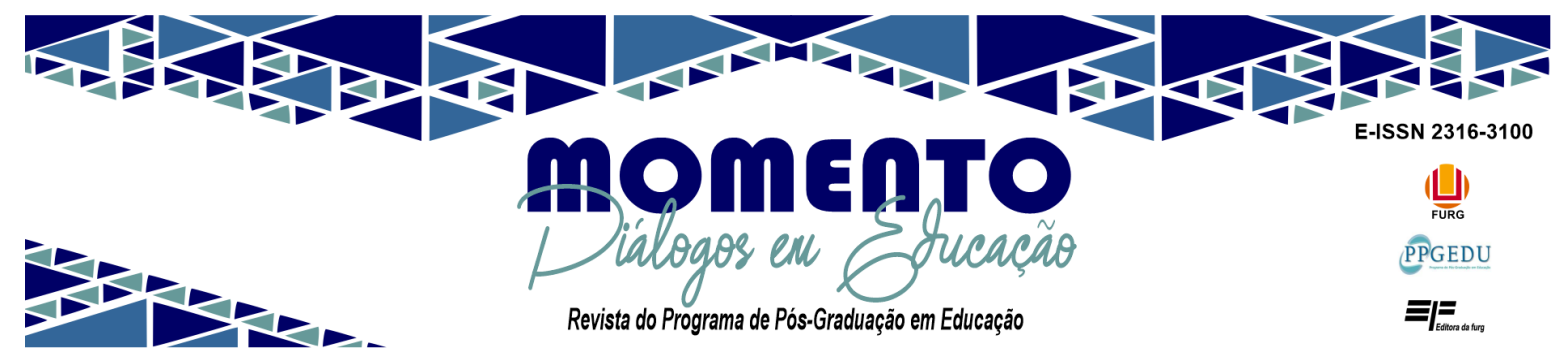

Eduarda: AS PA RE DE DES TE MOUVIDO (leitura da frase sem segmentação).

Pesquisadora: E essa aqui? (mostra frase segmentada de forma convencional)

Eduarda: AS PA RE DES TÊM O U VIDO (leitura da frase com segmentação convencional).

Observou-se que a criança mantém na primeira leitura o caso de híbrido 'te mouvido' (têm ouvido) que só desaparece no contato com a frase segmentada de forma convencional. Ao final, a criança julgou que a segunda forma, a segmentada de forma convencional, seria a melhor para ser lida porque as palavras ficavam mais separadas. Aproveitando a escolha da criança, a pesquisadora perguntou para Eduarda, quantas palavras tinham naquela frase $\mathrm{e}$ a criança contou segmentando da seguinte forma:

\section{As pa re des têm o u vi do}

Percebe-se o quanto a noção de palavra para Eduarda está fortemente ligada à sílaba, pois mesmo escolhendo a forma gráfica da frase com as palavras separadas conforme a norma, quando foi ler para contar quantas palavras continha, utilizou novamente como base para a contagem a sílaba. A diferença dessa segmentação em relação à anterior é que a criança, ao entender o sentido da frase, não rompeu mais com a estrutura monossilábica do verbo 'têm' e separou todas as palavras de forma silábica.

Na segunda coleta, nas duas primeiras etapas em que deveria ler e separar as palavras em barras, Eduarda leu, primeiramente, com certa dificuldade, e depois de reler realizou a seguinte segmentação em barras:

\section{O sol nas ce pa ra to dos}

No fragmento a seguir é possível acompanhar a segurança de Eduarda ao afirmar que cada sílaba é uma palavra:

Pesquisadora: Quantas palavrinhas têm aqui?

Eduarda: Uma, duas, três, quatro, cinco, seis, sete, oito (conta cada sílaba como sendo palavra).

Pesquisadora: Oito? 


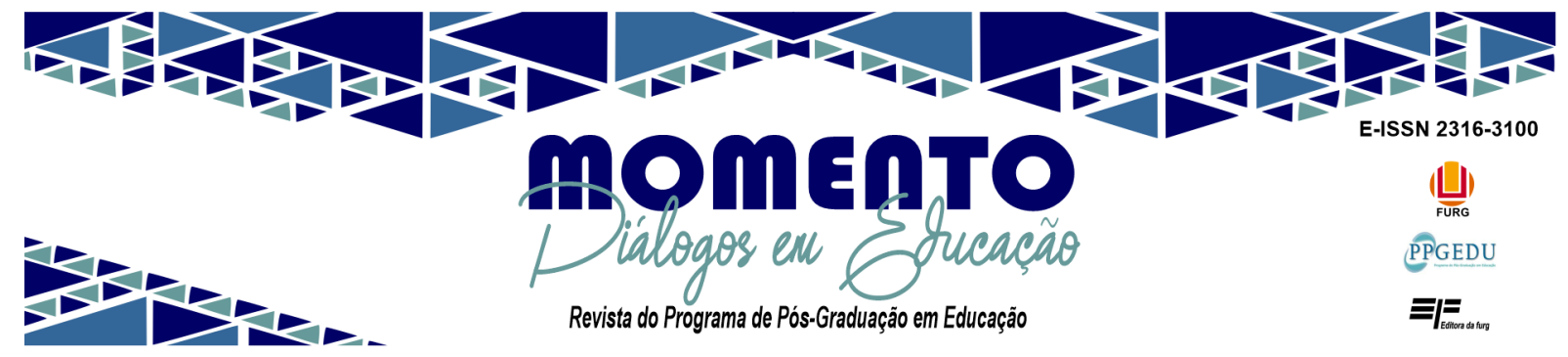

Eduarda: (concorda acenando com a cabeça)

Pesquisadora: Então cada pedacinho desses é uma palavrinha?

Eduarda: É.

Pesquisadora: Então 'o' é uma palavra? 'Sol' é outra?

Eduarda: Sol (fala junto com a pesquisadora)

Pesquisadora: 'nas' é outra?

Eduarda: É.

Pesquisadora: 'ce' é outra?

Eduarda: 'é' é outra (fala junto com a pesquisador)

Pesquisadora: 'pa'?

Eduarda: pa é outra.

Pesquisadora: 'ra'?

Eduarda: RA, TO, DOS

Pesquisadora: Então temos uma duas, três, quatro, cinco, seis, sete, oito.

Eduarda: quatro, cinco, seis, sete, oito (conta junto com a pesquisadora

Pesquisadora: Oito palavrinhas a gente têm aqui?

Eduarda: Hanram.

Esta noção de palavra como sílaba também foi verificada na tarefa seguinte, em que a criança precisou ampliar o número de quadradinhos para colocar cada sílaba como se fossem palavras segmentadas (Fig.02):

Figura 02 - Tarefa de segmentação em escrita contínua - Eduarda.

Obaratosaicaro

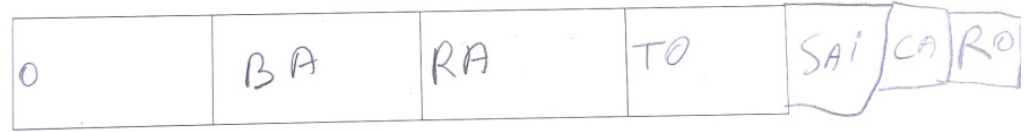

Tanto nesta tarefa quanto na anterior observou-se que na segmentação proposta pela criança não houve rompimento de sílaba como aconteceu na $1^{\mathrm{a}}$ coleta. Atribui-se a isso o fato de que nesta coleta as frases foram entendidas pela criança antes de iniciar a segmentação, ao contrário da frase da coleta anterior (As paredes têm ouvido), em que a criança só entendeu o seu significado no final das tarefas.

Observou-se que diante das duas formas da frase, com e sem segmentação convencional, na $5^{\text {a }}$ etapa, Eduarda, novamente, elegeu a segunda com segmentação convencional como a melhor para ser lida. Diante da resposta da criança a pesquisadora 




colocou esta frase junto à que Eduarda tinha segmentado dentro dos quadradinhos para que pudessem ser comparadas. A seguir, têm-se o trecho que a criança realizou a comparação:

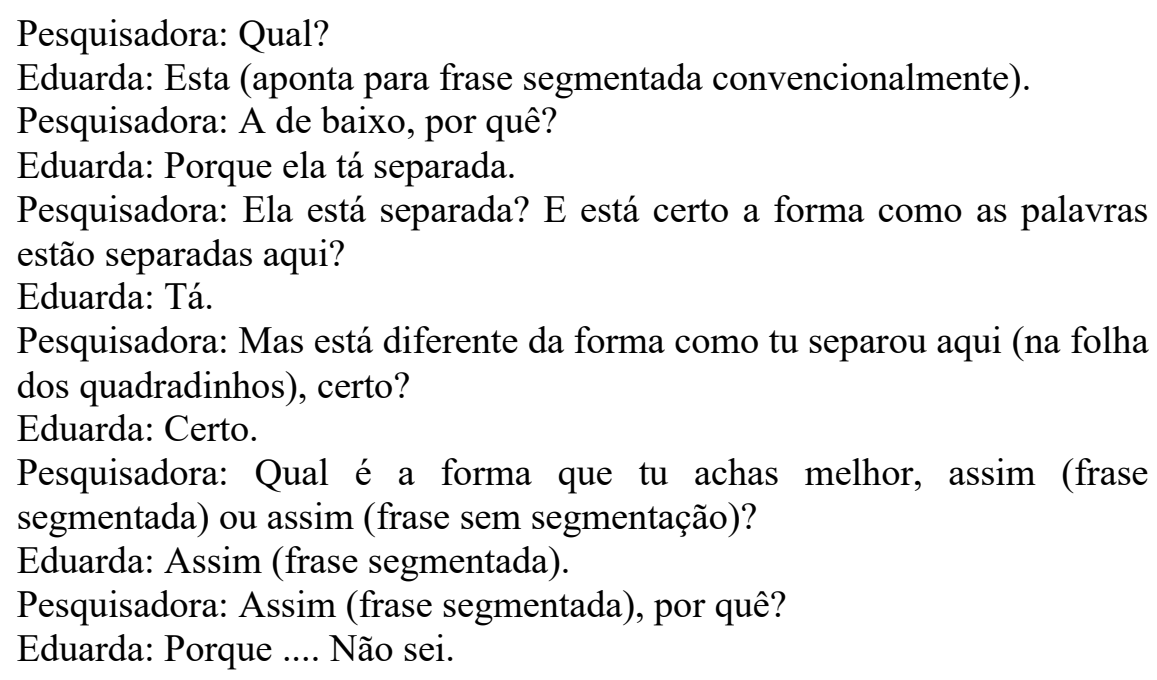

Viu-se que a criança escolheu como a forma mais adequada a que foi apresentada pela pesquisadora em relação a que realizou nos quadradinhos sem saber explicar o porquê da sua escolha. Convém salientar que a criança pode ter feito isso em função do grau de autoridade exercido pela folha mostrada pela pesquisadora que poderia ter sugerido que a segmentação da criança poderia não ser a correta. Mas mesmo que isso esteja correto, quando a pesquisadora solicitou que a criança contasse quantas palavras teria escrito nos quadradinhos, contou sete palavras, que conferem com a forma como segmentou as palavras $(\mathrm{O} / \mathrm{ba} / \mathrm{ra} / \mathrm{to} / \mathrm{sai} / \mathrm{ca} / \mathrm{ro})$. No entanto, quando foi contar o número de palavras que havia na frase segmentada, contou quatro (O/barato/sai/caro). Isso significa que a criança não contou com base na sílaba, como aconteceu na coleta anterior. Nesta $5^{\mathrm{a}}$ etapa (julgamento entre a frases com e sem segmentação das palavras), a criança contou cada palavra como estava exatamente segmentada de forma convencional mostrada pela pesquisadora.

$\mathrm{Na}$ terceira coleta, no final do ano letivo, a criança mais uma vez julgou que uma frase com as palavras sem segmentação não tem problema para ser lida e realizou a $2^{\circ}$ tarefa segmentando as palavras em barras da seguinte forma:

\section{Uma mão la va ao utra}




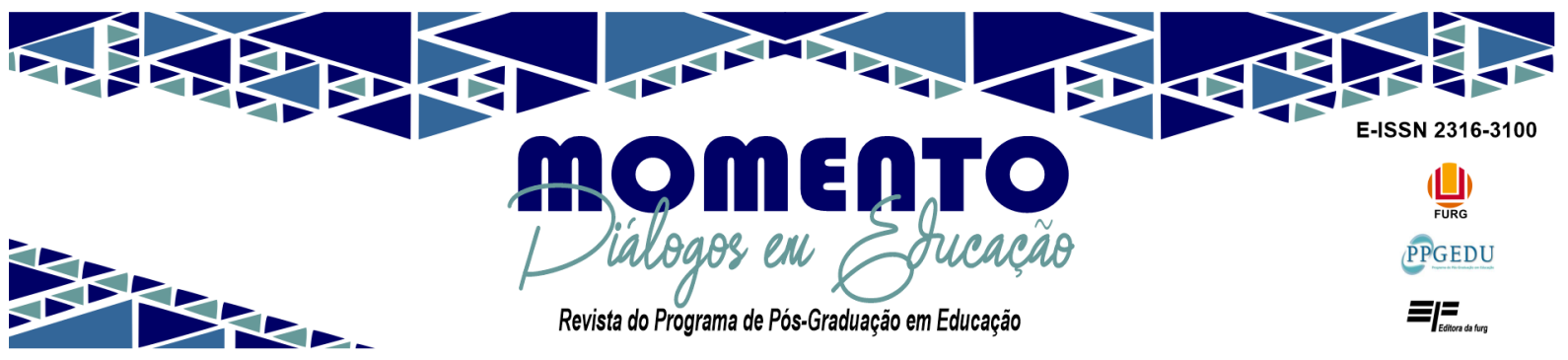

Após terminar a segmentação em barras a criança conferiu e contou seis palavras. Como se observou ela acabou gerando um caso de híbrido, 'ao utra' (a outra). Os casos de híbridos por serem estruturas que apresentam dois processos concomitantes, hipo e hipersegmentação, pressupõem mais de uma motivação (CUNHA, 2004). A partir da análise das gravações em que capturaram esse momento de escrita, percebeu-se que Eduarda verbalizava essa fragmentação nas palavras sem atentar para o conteúdo semântico vinculado.

$\mathrm{Na}$ frase que precisou colocar dentro dos quadradinhos, a criança não apresentou dificuldades em ler e segmentou quase todas as palavras de forma convencional:

\section{Quem vê cara não vê cora ção.}

Dessa vez a criança apresentou apenas um dado de hipersegmentação, na última palavra da frase, ‘cora ção' (coração) acrescentando apenas mais um quadradinho. Conforme análise das filmagens é possível perceber que nesse momento a criança parece estar mais preocupa em entender o que está sendo escrito. Repete várias vezes a frase enquanto escreve privilegiando o aspecto semântico.

E após, na última etapa, diante desta mesma frase escrita com e sem segmentação entre as palavras, a criança novamente escolheu a segunda como a melhor forma para ser lida. Como se pode verificar, Eduarda, parece atribuir sentido à segmentação como um recurso que auxilia na leitura. De acordo com Baez (1999), um dos critérios que parece ter maior consenso é o da legibilidade, pois as crianças percebem a segmentação como algo necessário para garantir o ordenamento e a significação do texto.

A noção de palavra ligada à sílaba nas concepções de Eduarda mostra oscilações até o final do ano letivo, diminuindo gradativamente. Assim como a sua percepção a respeito da segmentação vocabular como um recurso gráfico que auxilia, em especial, a compreensão do que está escrito. O que remonta a própria origem das segmentações, pois os espaços gráficos que conhecemos hoje, aceitos como naturais, são o resultado de um longo processo histórico, que com advento da imprensa, a separação gráfica entre as palavras surgiu como 


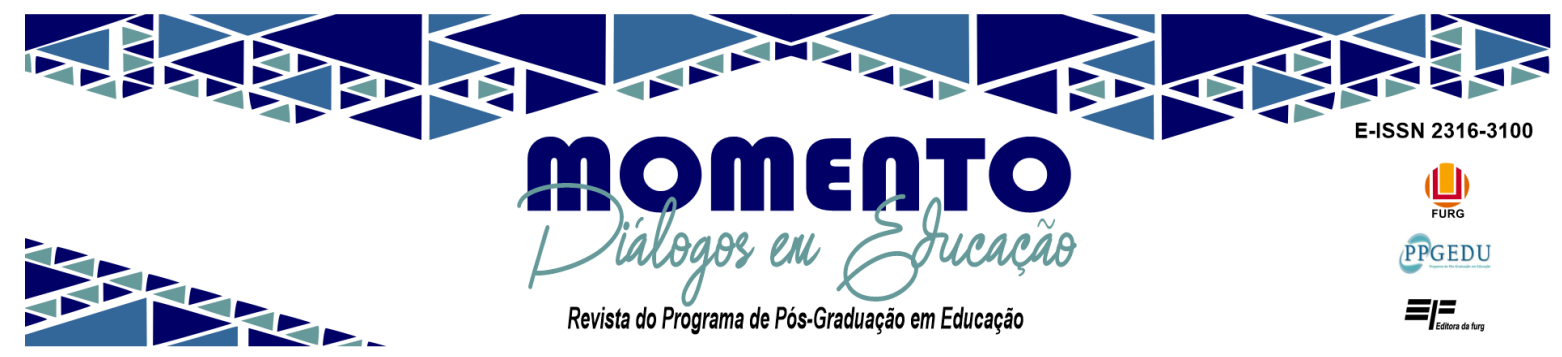

a necessidade de criar formas mais precisas que orientassem a leitura dos textos (ROSA, 2006).

\section{Considerações finais}

Os dados analisados no presente artigo parecem reforçar a complexidade do processo de aquisição do sistema de escrita no que se refere à noção de palavra por crianças em fase de alfabetização. Os critérios que influenciaram as escolhas infantis de onde segmentar, por vezes, podem ter como base critérios prosódicos ou semânticos. O contorno entonacional no momento de escrita pode gerar casos de hipossegmentação, hipersegmentação e de híbridos. As crianças investigadas não pareciam ainda conceber a segmentação como um aspecto formal próprio do sistema de escrita, que segue uma regularidade. Quando questionadas sobre a possibilidade de contar as palavras escritas oscilavam entre a base silábica e as estruturas segmentadas de forma não convencional como os casos de hipossegmentação.

Convém ressaltar que a interpretação do que as crianças estavam realmente concebendo como palavra só foi possível porque além do registro gráfico considerou-se as justificativas infantis. Viu-se que apenas a escrita como produto final revela muito pouco sobre o que elas estão realmente concebendo como palavra. Em alguns episódios foi possível verificar que embora tenham delimitando corretamente os espaços entre as palavras, não consideram cada estrutura como sendo uma palavra porque continuam, por vezes, ancorados na hipótese do número mínimo de letras para considerar como palavra. Isso significa dizer que nem sempre o que se observa graficamente na escrita da criança sobre os limites de palavra, pode-se atribuir ao entendimento do que seja uma palavra pela ótica infantil.

Tais justificativas também revelaram o aspecto semântico atribuído à segmentação como um recurso que facilitaria a compreensão do que se estaria lendo. Quando questionadas se seria possível ler uma frase toda hipossegmentada, disseram que sim. No entanto, no decorrer das tarefas, mais precisamente na última etapa, em que precisavam decidir se a melhor forma de uma frase seria com as palavras todas hipossegmentadas ou 


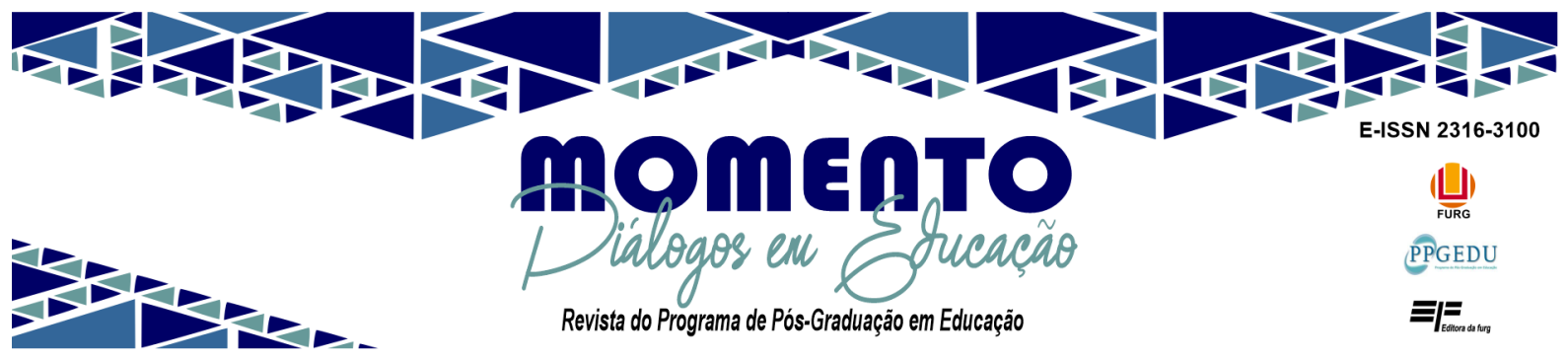

segmentadas conforme a norma, ao confirmarem que seria possível ler uma frase sem espaços entre as palavras, estavam na verdade respondendo: sim, eu consigo verbalizar o que está escrito aí. Sendo assim, pode-se pensar que, segundo as concepções infantis, ler não corresponde necessariamente ao processo de compreensão do que está escrito, ou seja, a ação de ler não tem como primeira instância a inteligibilidade.

Considera-se fundamental reiterar, que tais resultados, além de esclarecerem aspectos sobre o funcionamento das segmentações não convencionais, podem subsidiar reflexões a respeito do modo como o processo de aquisição da escrita da palavra vai se constituindo sob a ótica de quem aprende. Essa é uma contribuição relevante para comunidade infantil, uma vez que se valoriza o pensamento das crianças frente ao objeto de estudo, considerando-as como sujeitos ativos no processo de aprendizagem.

Conhecimentos como esses sobre o processo e funcionamento da língua a respeito da delimitação das palavras por espaços em branco, permite ao alfabetizador(a) avaliar as produções iniciais de crianças sem se deter apenas nos aspectos gráficos dessas produções, mas nos aspectos construtivos representativos de um processo cognitivo em vias de evolução. Isso não quer dizer, porém, que o(a) professor(a) seja mero espectador do processo de desenvolvimento da escrita; pelo contrário, ele(a) desempenha papel de fundamental importância no processo de aquisição da escrita, à medida que, destituído de suas posições fortemente marcadas por aquelas típicas de um adulto alfabetizado, consiga entender que aquilo que parece incoerente para ele(a) é extremamente coerente para o aluno, dadas as hipóteses que ele está (re)formulando sobre o sistema de escrita. Portanto, saber 'ler' a escrita inicial dos aprendizes requer dos(a) professores(as) alfabetizadores(as) ações pedagógicas alicerçadas em reflexões linguísticas e de uma clara base epistemológica.

Destaca-se, por fim, a importância de se propor atividades pedagógicas sobre o sistema de escrita alfabética, que possam deixar a criança expressar o que está concebendo sobre os aspectos normativos da língua, a valorização dessa escuta atenta, parece ser o ponto central dessa questão, e não restringir o questionamento ao que parece pertinente ao adulto, seja pesquisador ou docente.

\section{Referências}




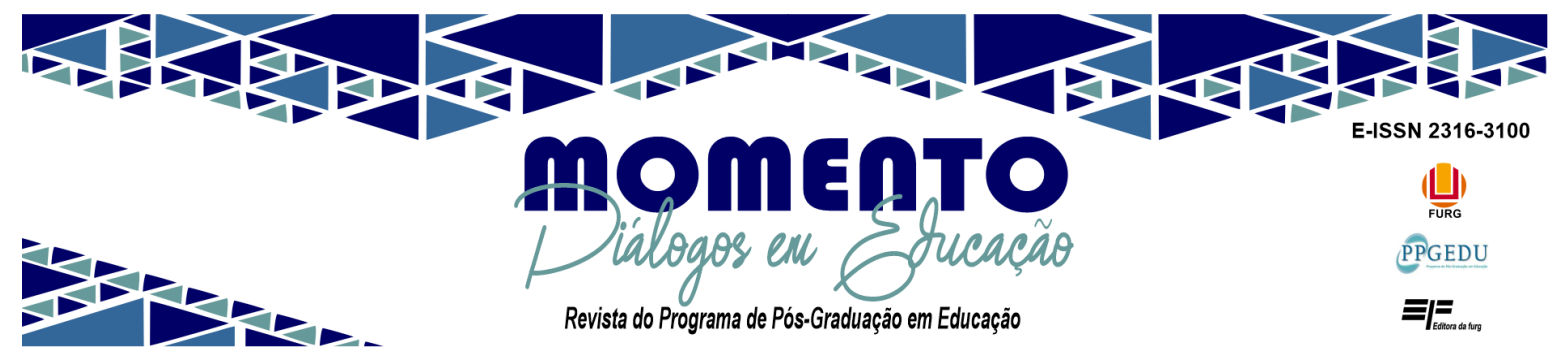

ABAURRE, M. B.; CAGLIARI, L.C. Textos espontâneos na $1^{\mathrm{a}}$ série: evidências da utilização, pela criança, de sua percepção fonética da fala para representar e segmentar a escrita. Em: Cadernos CEDES 14, Recuperando a alegria de ler e escrever. São Paulo: Cortez Editora. (pp. 25-29). 1985.

ABAURRE, M. B. A relevância dos critérios prosódicos e semânticos na elaboração de hipóteses sobre segmentação na escrita inicial. Boletim da ABRALIN, 1991.

ABAURRE, M. B.; SILVA, A. O desenvolvimento de critérios de segmentação na escrita. Temas em psicologia. São Paulo, v.1, p. 89-102, 1993.

ABAURRE, M. B; Fiad, R., \& M. L. Mayrink-Sabinson. Cenas de Aquisição da Escrita: o trabalho do sujeito com o texto. Campinas: Mercado de Letras. 1997.

BAEZ, M. La problemática de segmentar el texto escrito en palabras: una indagación psicolinguística. In: BAEZ, M; CÁRDENAS, V. I. Segmentación y escritura. Dos estudios sobre adquisición. Ed. Homo Sapiens. Rosario,1999.

BISOL, L. (org.). Introdução a estudos de fonologia do português brasileiro. Porto Alegre: EDIPUCRS, 1996.

BOGDAN, R.; BIKLEN, S. Investigação Qualitativa em Educação: uma introdução à teoria e aos métodos. Portugal: Porto Cedez, 1994.

CAGLIARI, L. C.; MASSINI-CAGLIARI, G. Diante das letras: a escrita na alfabetização. Campinas: Mercado das Letras, 1992.

CAGLIARI, L. C. Alfabetização \& Linguística. São Paulo: Editora Scipione, 2002.

CAPRISTANO, C.C. Aspectos de segmentação na escrita infantil. São José do Rio Preto: 2003. Dissertação (Mestrado em Estudos Linguísticos). Instituto de Biociências, Letras e Ciências Exatas (IBILCE), Universidade Estadual Paulista (UNESP).

CAPRISTANO, C.C. Mudanças na trajetória da criança em direção à palavra escrita. 2007. 245p. Tese de Doutorado em Linguística Aplicada, Instituto de Estudos da Linguagem, Universidade Estadual de Campinas, Campinas.

CAPRISTANO, C.C. Por uma concepção heterogênea da escrita que se produz e que se ensina na escola. Cadernos de Educação. Ano 19 n.35, Ed. UFPel- Pelotas, RS - JaneiroAbril 2010.

CAPRISTANO, C.C.; CHACON, L. Relações metafóricas e metonímicas: notas sobre a "aquisição" da noção de palavra. In: TFOUNI, L. V.; TONETO, D. J. (Org.) O (In) esperado de Jakobson. Campinas: Mercado de Letras, 2014. 


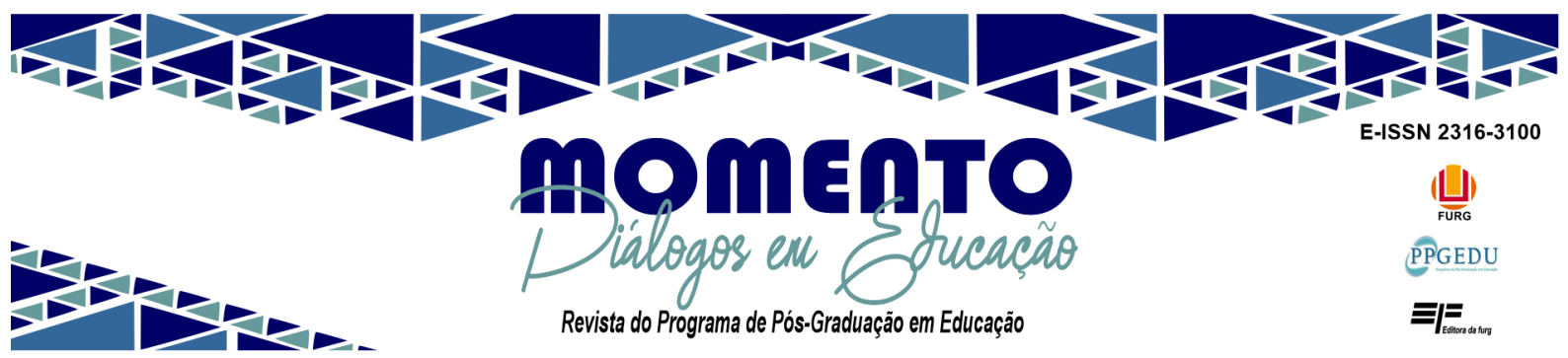

CARRAHER, T. N. O Método Clínico: usando os exames de Piaget. São Paulo: Cortez, 1989.

CATACH, N. Hacia uma teoria de la lengua escrita. Barcelona, Gedisa. 1996.

CHACON, L. Constituintes prosódicos e letramento em segmentações não-convencionais. Letras de Hoje, Porto Alegre, v. 39, n. 3, 2004, p. 223-232.

CHACON, L. Hipersegmentações na escrita infantil: entrelaçamento de práticas de oralidade e de letramento. Estudos Linguísticos, Campinas, v. 34, 2005, p. 77-86.

CHACON, L. Prosódia e letramento em hipersegmentações: reflexões sobre a aquisição da noção de palavra. In: CORRÊA, M. L. G. (org.) Ensino de língua: representação e letramento. Campinas: Mercado de Letras, 2006, p. 155-167.

CORRÊA, M. L. G. O modo heterogêneo de constituição da escrita. São Paulo: Martins Fontes, 2004.

CUNHA, A. P. N. A hipo e a hipersegmentação nos dados de aquisição da escrita: um estudo sobre a influência da prosódia. Pelotas, 2004. 132p. Dissertação (Mestrado em Educação) - Universidade Federal de Pelotas.

CUNHA, A. P. N. As segmentações não convencionais na escrita inicial: uma discussão sobre o ritmo linguístico do português brasileiro e europeu. Pelotas, 2010. 190p. Tese (Doutorado em Educação) - Universidade Federal de Pelotas.

FERNANDES, N. Infância, Direitos e Participação: Representações, Práticas e Poderes. Porto: Edições Afrontamento, 2009.

FERREIRO, E. Com todas as letras. São Paulo: Cortez, 1991.

FERREIRO, E.; PONTECORVO, C. Os limites entre as palavras. A segmentação em palavras gráficas. In: FERREIRO, E. PONTECORVO, C., HIDALGO, I. G. Chapeuzinho Vermelho aprende a escrever. São Paulo: Ática, p.38-66, 1996.

FERREIRO, E.; TEBEROSKY, A. Psicogênese da língua escrita. Porto Alegre: Artes Médicas Sul, 1999.

FERREIRO, E. Reflexões sobre a alfabetização. São Paulo: Cortez, 2004.

FERREIRO E.; VERNON C. (1992), La distinción palavra/nombre em niños de 4 e 5 años In: FERREIRO. E. O ingresso na escrita e nas culturas do escrito: seleção de textos de pesquisa. São Paulo Ed.: Cortez, 2013. 


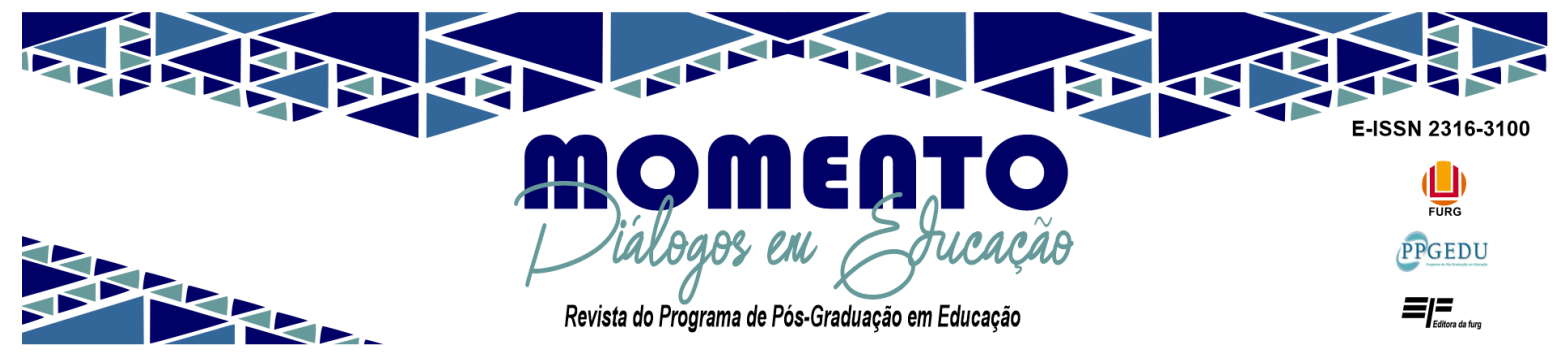

FERREIRO. E. O ingresso na escrita e nas culturas do escrito: seleção de textos de pesquisa. São Paulo Ed.: Cortez, 2013.

GIL, A. C. Como elaborar projetos de pesquisa. São Paulo: Atlas, 2007.

MATTOSO C. Jr., J. História e Estrutura da Língua Portuguesa. Rio de Janeiro: Padrão, 1969.

NESPOR, M.; VOGEL, I. La Prosodia. Madrid: Visor Distribuciones, S.A., 1986.

PAULA, I. F. V. Movimentos na escrita inicial de crianças: um estudo longitudinal de hipersegmentações. São José do Rio Preto, 2007. 132p. Dissertação (Mestrado em Estudos Linguísticos) - Universidade Estadual Paulista.

PONTES, E. O tópico no português do Brasil. Campinas: Pontes, 1987.

ROSA, M. C. Introdução à morfologia. São Paulo: Contexto, 2006.

TENANI, L. E. Segmentações não-convencionais e teorias fonológicas. Letras de Hoje, Porto Alegre, v. 39, n. 3, p. 233-244, 2004.

Submetido em: 13-03-2021

Aceito em: 30-07-2021 